\title{
Analysis of Students Report Writing from SFL-GP Perspective and its Relation to Students Proficiency
}

\author{
Monalisa Pasaribu ${ }^{1}$, Tiurma Lumban Gaol ${ }^{2}$ and Hernawati Samosir ${ }^{3}$ \\ ${ }^{1}$ Program Studi Diploma 3 Teknologi Informasi, Institut Teknologi Del, Indonesia \\ *Corresponding Author: monalisa.pasaribu@del.ac.id
}

\begin{abstract}
ABSTRAK
Penulisan laporan hasil proyek merupakan salah satu ketrampilan yang harus dimiliki oleh mahasiswa, khususnya pada mahasiswa program Teknologi Informasi. Penelitian ini bertujuan untuk menyelidiki bagaimana mahasiswa Program Teknologi Informasi melakukan penulisan laporan proyek berdasarkan teori Genre Pedagogy dan untuk mengidentifikasi hubungan antara pengetahuan mahasiswa terkait pengetahuan SFL GP dengan kemampuan berbahasa. Metode yang dilakukan dalam penelitian ini adalah metode kualitatif dan kuantitatif. Metode kualitatif dilakukan dengan menganalisa variabel field, tenor dan mode serta tingkatan genre dari 15 laporan Proyek Akhir Mahasiswa. Hasil ini selanjutnya dipetakan dengan kemampuan Bahasa dari setiap mahasiswa menggunakan Pearson correlation. Hasil penelitian menunjukkan sebanyak $13.3 \%$ laporan menggunakan genre procedural recount dan $86.6 \%$ menggunakan genre descriptive report. Dari pemetaan terhadap kemampuan berbahasa Inggris mahasiswa, hasil menunjukkan adanya hubungan yang kuat (0.775) antara pengetahuan genre dengan kemampuan Bahasa mahasiswa.
\end{abstract}

Kata kunci: Systemic Functional Linguistics, Genre Pedagogy, penulisan laporan

\begin{abstract}
Project Report Writing is an important skill to have students in tertiary education, including students of Information Technology Diploma. This research aims to investigate how students write their report using Genre Pedagogy and identify the relationship between students knowledge of SFL GP and their language proficiency. Both qualitative and quantitative methods are used in this research. The qualitative method analyzes the genre's field, tenor, mode, and stage from 15 Final Project reports. The result is then mapped to students language proficiency using Pearson correlation. The result shows that $13.3 \%$ of the reports are written in the procedural recount genre, and 86.6\% are written in the descriptive report. At the same time, the mapping indicates strong relation (0.775) between the genre knowledge and students language proficiency.
\end{abstract}

Keywords: Systemic Functional Linguistics, Genre Pedagogy, report writing

\section{INTRODUCTION}

Among the skills in English teaching, speaking and writing are included as productive skills. The students are demanded to utilize the language either in oral communication or in writing. Particularly to writing, academic writing is taught extensively for students in tertiary education. Academic writing may be formed in, for example, a book, research paper, journal article, or report writing. The necessity of equipping the students with such skills develops not only the professional responsibility [1]. But more fundamentally, there has been discussion over significant fall-off of students ability to consider sophisticated aspects of writing - the analytical elements. [2], This means it is necessary to bring about academic writing in tertiary education, for it brings numerous beneficial, regardless of the students' majors.

In the class of Diploma of Informatics Engineering, one of Information and Technology (IT) major in Del Institute of Technology, as part of the academic requirement for students, they are demanded to submit a report of their final project [3]. The report consists of the report on the conduct of the project that the students have done over a two-semester period related to software development. From the beginning of the first semester- students are given some topics for their report, and over the semester, they will develop 
software in the form of a mock-up and test it to the prospective users in this case- the lecturer. The result of the software development and testing is to be written in the form of a report.

From the linguistic perspective, science differs from everyday language in several respects and, therefore often considered difficult [4]. This indicates that some aspects may vary in the delivery of science-related topics, including in writing. Moreover, English teaching in writing may not be considered as demanding a subject as the core subjects such as computer science-related subjects [5]. This means English topics for students in science may be less prioritized, let alone for the academic writing for science students.

Apart from the reasons above, one empowering English teaching approach, Systemic Functional Linguistics, views writing as a shared experience between learners and teachers. The shared experience helps learners to produce writings. In this regard, regardless of the major of learners, as long as they are exposed to English texts, they may know how to do the writing.

Therefore, this paper will investigate how the report writing is done by IT students, specifically the genre used in the report's writing.

Therefore, two questions were raised for this research:

1. Information Technology students in writing commonly use what types of genres?

2. What is the relation between the knowledge of genres with students language proficiency?

\section{LITERATURE REVIEW}

\section{A. Systemic Functional Linguistics}

Systemic Functional Linguistic (SFL) is one approach to English teaching. SFL sees how text functions are analyzed within its context of culture and context of the situation. Genre pedagogy (GP) in SFL focuses on the meaning-making process through writing. Genre analysis has been used as an instructional method across variety of context to help scaffold students knowledge to meet the particular socio-rhetorical goals of a writing task so that students become aware of how text and context are connected [6]. SFL also deals with the register of three variables. Coined first by Halliday in 1978 [7], these variables are also known as semiotic functions Field, Tenor, and Mode. Field deals with which the texts are for. While tenor deals with the relationship between those involved in the text, mode deals with the means of communication used.

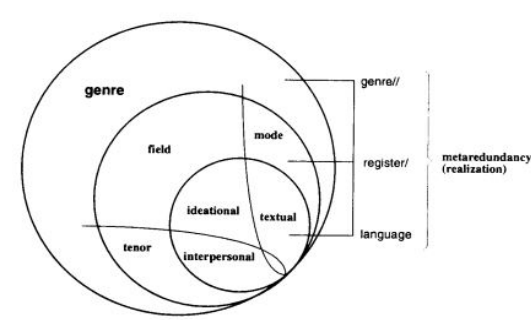

Fig. 1. Functional diversification of language and social context [8]

Looking at the figure shows a clear relationship between the context and the context of the situation. In the simple explanation, a text informs about a past holiday activity by a 7-year-old child. The register for the text may look like: past holiday (field), friends (tenor), and informal text writing (mode), a genre of a recount. And, as for the genre, since the situation is about the past holiday, the genre will indicate that it executes the recount genre.

\section{B. Genre Analysis and Register}

One of SFL's prominent projects, called Writing Project, resulted in the genre pedagogy that empowers young-age students to produce writing during school [8]. This genre scaffolds the writing through deconstruction, joint-construction, and independent construction processes. It was formally included in the Indonesian curriculum [9]. Researchers have also investigated the use of SFL GP at many different levels, for example, in high school [10] and at the tertiary level [11]

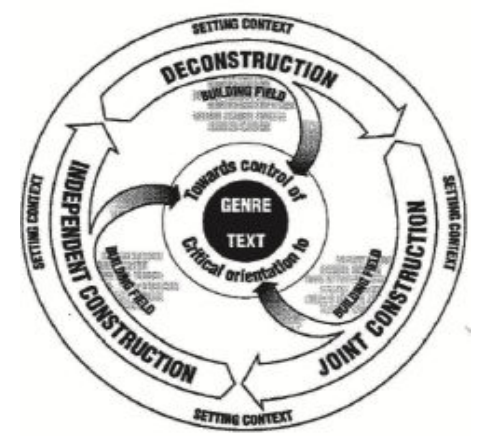

Fig. 2. Teaching cycle in SFL GP [8]

Research by Myskow on genre analysis in the writings of secondary school students [12] showed that their writings improved after the treatment of genre pedagogy they were exposed to during the teaching and learning process. His further research 
[13] includes the genre discussion for the second language novice learners with positive results where students have a deeper understanding of writing. Exposing the students to many text examples and exercising on registering the text using field, tenor and mode did benefit their writing.

Rivera s research [14] discussed the positive impact of genre pedagogy towards the writing process and oral communication. As a result, the class became more communicative during the discussion since the students shared their understanding of the context. The cycle of deconstruction, joint construction, and individual construction motivated the students in Rivera $s$ class to be more active in producing language orally.

Most of the research conducted discussed the positive impact of genre pedagogy and the use of the register to improve students' writing. However, discussions related to the genre analysis of writing produced by science students were discussed at a minimum level. Research by Padyab, Päivärinta, and Harnesk [15] examined the use of genre to assess information and technology security, yet does not discuss its use for writing improvement. Moreover, the process of meaning-making in the science class was mentioned by Mortimer and Scott [4] in their book, yet their discussion was only for secondary school.

\section{METHODS}

This research used both qualitative and quantitative methods in the data collection. The qualitative approach aims to understand the complexity of a particular, while the quantitative aims to have objective measurements of numerical analysis of data collected [16]. In the data explanation, descriptive analysis is used for detail and in-depth explanation of the results of statistical correlation by Pearson Correlation Coefficient test.

As many as fifteen reports were gathered for the research. The report was written by 59 Informatics Engineering students in their final semester of the second year Diploma program. This report writing is part of an assignment from the Yearly Final Project. At the end of the 4th semester, all the reports are collected from the students. The students average score was taken from their English score in English I

English III. The score consists of the assignment, quiz, mid-term exam, and final-term exam.

\section{ANALYSIS}

\section{A. Genre Analysis}

Using the identification by Rose and Martin [8], the qualitative data were then grouped into the genre by registering the variables of field, tenor, and mode and stages of the genre. $13.3 \%$ (2 reports) used procedural recount genre, following the stage of classification description. These two reports executed the procedural recount by first classifying the method in developing the software and describing the users' response towards the software use.

The use of descriptive report genre dominated the reports. 86.6\% (13 reports) used it, following the stage of purpose method result. The dominancy of descriptive pedagogy may be due to the instruction of the assignment in which students are to develop software; however, were not continued to the users' responses.

\section{B. Mapping to students language proficiency}

After identifying the genre of report used by the students, the analysis continues to answer the second research question to find out the relationship between the knowledge of genres with students language proficiency. The writings were given a score based on the rubric by the course designer. These scores were then compared with students average English score from English I III. The correlation is done using the statistical correlation of the Pearson Correlation Coefficient test.

\begin{tabular}{|c|c|c|c|}
\hline \multicolumn{4}{|c|}{ Correlations } \\
\hline & & Writing Score & Final score \\
\hline \multirow[t]{3}{*}{ Writing Score } & Pearson Correlation & 1 & .775 \\
\hline & Sig. (2-tailed) & & .000 \\
\hline & $\mathrm{N}$ & 59 & 59 \\
\hline \multirow[t]{3}{*}{ Final score } & Pearson Correlation & $.775^{\prime \prime}$ & 1 \\
\hline & Sig. (2-tailed) & .000 & \\
\hline & $\mathrm{N}$ & 59 & 59 \\
\hline
\end{tabular}

Fig. 2. Pearson correlation of students knowledge and proficiency

From this figure, the test result indicates that the understanding of SFL GP and students English proficiency has a strong correlation (0.775). This strong relation suggested that the knowledge of language proficiency of students affected their SFL GP knowledge.

\section{DISCUSSION AND CONCLUSION}

Genre pedagogy is related to the shared experience among learners. Research indicated that the knowledge of student's Information Technology 
SFL GP is correlated with their proficiency. This shows that students prior knowledge of the language may also affect their knowledge of SFL GP. It may happen because the students are familiar with the terms discussed in the text. Moreover, sharing experiences amongst the learners may also help them identify the genres' patterns for the reports. And since this report writing has been done for years, senior students may also have shared the knowledge of report writing with their juniors.

This research affirms Rose and Martin s notion of Knowledge of Language (KAL) [8]. Through the identification of semantic patterns, students have the metalanguage knowledge to construct the text. It also helps to analyze the language functions better to build the ideas and manage the following information in the text. Moreover, as Hyland stated [6], shared experience may involve everyday domestic expertise. This may also influence students since they frequently encounter their friends.

Academic writing as the primary concern of the research should also become one thing to consider for future research. Students equipped with better knowledge of academic writing tend to have better analytical skills. Therefore, the further focus may be on the depth analysis of their analytical skill through experimental research by giving the treatment of SFL-GP to the IT students. This can be done for a better result of academic writing.

\section{BIBLIOGRAPHY}

[1] S.D. Anderson, "Project quality and project managers. International". Journal of Project Management, vol. 10, no.3, pp. 138-144, 1992.

[2] M.J. Benner, and M. L. Tushman, "Exploitation, exploration, and process management: the productivity dilemma revisited", Academy of Management Review vol. 28, no. 2, pp. 238256, 2003.

[1] E. Arneback, T. Englund, and T. D. Solbrekke, Achieving a professional identity through writing, Educ. Inc., vol. 8, no. 4, pp. 284 298, 2017.

[2] L. Ganobcsik-William, A Report on the Teaching of Academic Writing in UK Higher Education. University of Warwick, 2004.

[3] Tim-Dosen, Buku Kurikulum Diploma 3 Teknik Informatika 2016 - 2019 Institut Teknologi Del. unpublished, 2016.

[4] E. Mortimer and P. Scott, Meaning-making in secondary science classrooms. PA: Open University Press, 2003.
[5] D. Passey, Computer science (CS) in the compulsory education curriculum: Implications for future research, Educ. Inf. Technol., vol. 22, no. 2, pp. $421 \quad 443,2017$.

[6] K. Hyland, Genre, and second language writing. Michigan, US: Cambridge University Press, 2004.

[7] M. A. K. Halliday, Language as social semiotic: the social interpretation of language and meaning. London: Edward Arnold, 1978.

[8] D. Rose and J. . Martin, Learning to write, reading to learn: Genre, knowledge, pedagogy in the Sydney school. Sheffield: Equinox, 2012.

[9] E.-I. Minister-of-National-Education, The 2004 curriculum: Competence standards: English for senior high schools. Jakarta: Indonesian Ministry of National Education.

[10] M. Rahman and Tartila, The implementation of the genre-based approach in English teaching at Islamic Senior High School Model (Man Model) Jambi, Reflective, vol. 4, no. 1, pp. 28 36, 2013.

[11] E. Emilia and F. . Hamied, Systemic functional linguistic genre pedagogy (SFL GP) in a tertiary EFL writing context in Indonesia, TEFLIN J., vol. 26, no. 2, pp. 155 182, 2015.

[12] G. Myskow and K. Gordon, A focus on purpose : Using a genre approach in an EFL writing class, ELT J., vol. 64, no. 3, pp. 28 292, 2010.

[13] G. Myskow, Genre analysis for novice L2 writers: Sample activities and suggestions for implementation, pp. 13 26, 2012.

[14] J. D. . Rivera, Using a genre-based approach to promote oral communication in the Colombian English classroom, Columbian Appl. Linguist. J., vol. 14, no. 2, pp. 109 126, 2012.

[15] A. Padyab, T. Päivärinta, and D. Harnesk, Genre-Based Assessment of Information and Knowledge Security Risks, 47th Hawaii Int. Conf. Syst. Sci., pp. $3342 \quad 3451,2014$.

[16] L. Kervin, W. Vialle, S. Howard, J. Herrington, and T. Okely, Research for Educators, 2nd Edition. Vic: Cengage Learning Australia, 2015. 